\title{
Religião, arte e política na \\ controvérsia pública da \\ Igrejinha da Pampulha
}

DoI

http://dx.doi.org/10.11606/ 2179-0892.ra.2017.141651

\section{Paola Lins de Oliveira}

- Universidade do Estado do Rio de Janeiro / Rio de Janeiro, RJ, Brasil

$\mathbf{v}$ paolalins@gmail.com

\section{RESUMO}

O artigo apresenta uma reflexão sobre os primeiros anos da biografia cultural da Igreja de São Francisco de Assis, situada no bairro da Pampulha, Belo Horizonte - MC. A Igrejinha da Pampulha se insere em um plano de modernização urbana idealizado no início dos anos de 1940 pelo então prefeito da capital mineira, Juscelino Kubitschek, que dá origem ao Conjunto Arquitetônico da Pampulha. Com projeto do arquiteto Oscar Niemeyer e programa decorativo encabeçado pelo artista plástico Cândido Portinari, a edificação é recusada pelas autoridades religiosas mineiras, estabelecendo uma controvérsia pública entre defensores e críticos de sua consagração religiosa. O interesse que ancora esta análise está no modo como a edificação fundamenta, condensa e estimula consórcios entre as dimensões religiosa, artística e também política, ao mesmo tempo em que seus idealizadores, críticos e defensores oscilam entre, de um lado, a sustentação de tais associações e, de outro, a aposta nas distinções entre as mesmas dimensões, tanto para defendê-las quanto para criticá-las. Trata-se portanto de um caso no qual está em jogo o tensionamento constante do paradigma moderno de separação e autonomia das instâncias religiosas, artísticas e políticas. 


\section{INTRODUÇÃO'}

No início dos anos de 1940, a Igreja de São Francisco de Assis fora encomendada pelo então prefeito da capital mineira, Juscelino Kubitschek, ao arquiteto Oscar Niemeyer no âmbito do planejamento de um complexo arquitetônico a ser desenvolvido para uma região em expansão da cidade, a da barragem da Pampulha. Dentro do conjunto de edifícios composto por uma Casa de Baile, um Cassino, um late Club e um Hotel, Kubitschek imaginava uma igrejinha pequena, à beira do lago formado pela água da barragem, devotada a São Francisco de Assis, santo pelo qual tinha particular apreço. Niemeyer projeta cinco edificações com partidos arquitetônicos pouco convencionais: linhas simplificadas e sinuosas, soluções inovadoras para as fachadas, coberturas e para a integração dos volumes internos e externos. Assim também é elaborada a igrejinha sonhada por Kubitschek, com seu teto conformado em abóbadas parabólicas de concreto armado, sua torre de base estreita progressivamente alargada em direção ao cume portando o sino, entre outras "surpresas" arquitetônicas já características da obra do arquiteto-revelação. Com o intuito de completar sua criação, Niemeyer convida artistas para decorar as edificações. A Igrejinha da Pampulha ganha mosaicos abstratos de Paulo Werneck nas laterais externas da cobertura, baixos-relevos para o batistério de Alfredo Ceschiatti, e diversas obras de Cândido Portinari: painéis de azulejos, via-crúcis, afresco do altar e um mural de azulejos externos.
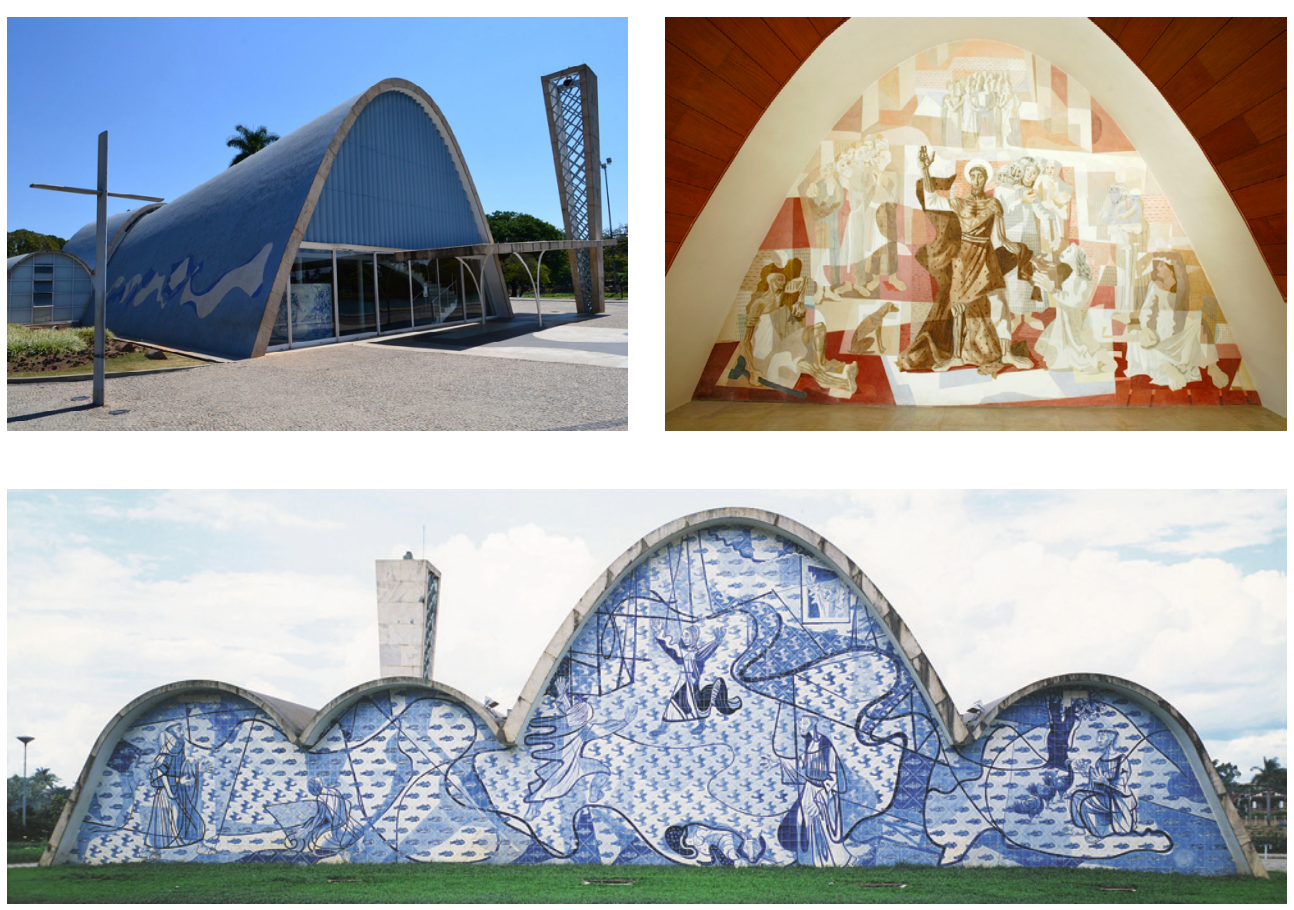

1 Este artigo parte originalmente das principais reflexões desenvolvidas no primeiro capítulo da minha tese de doutorado sobre a idealização, construção e recepção inicial de duas obras-lugares: a Igrejinha da Pampulha (Belo Horizonte, MG-Brasil) e a Capela do Rosário (Vence, Alpes Marítimos - França) (Oliveira, 2014). Agradeço aos pareceristas pelas valiosas sugestões que permitiram a ampliação e aperfeiçoamento do argumento inicial.

\section{Figura 1}

À esquerda, entrada frontal da Igreja de São Francisco de Assis da Pampulha

\section{Figura 2}

À direita, mural "São Francisco se despojando das vestes" de Portinari

\section{Figura 3}

Fachada posterior da Igreja de São Francisco de Assis da Pampulha com mural de azulejos (s/título) de Portinari 
Mas antes mesmo de ser concluída, a Igrejinha é posicionada no centro de uma polêmica que ameaça seu futuro: trata-se da recusa do arcebispo belorizontino em consagrar a edificação para uso religioso. Para justificar sua posição, o arcebispo lança mão de argumentos que sublinham o alheamento da Igreja Católica em relação ao desenvolvimento do projeto da Igrejinha, bem como suas características modernas desconformes com aquelas que deveria ostentar uma "casa de Deus". A declaração de d. Antonio dos Santos Cabral é publicada em um jornal de grande circulação regional em agosto de 1946 e a partir dela instala-se um debate público entre defensores e opositores da sua consagração - o que manterá a Igrejinha fechada durante quatorze anos.

Neste artigo, analiso o caso da Igrejinha da Pampulha a partir dos registros textuais e iconográficos ${ }^{2}$ do período de recepção inicial da edificação, tomando como horizonte reflexivo a noção-chave de controvérsia pública. Aqui, sigo a linha interpretativa proposta por Giumbelli (2002a; 2002b), para quem as polêmicas e controvérsias públicas podem ser pensadas como dramas sociais com potencial para simultaneamente revelar e reconfigurar definições da realidade social. Nesse sentido, Bruno Latour (2005) argumenta que à medida que atores sociais se engajam em uma controvérsia, instauram-se laços entre aqueles que compartilham um posicionamento, combinações de novas argumentações surgem, ao mesmo tempo em que se vislumbram as fronteiras em relação àqueles que são percebidos como opositores. Seguir uma controvérsia, observar os caminhos que os atores constroem, as conexões entre argumentos e posições, as rupturas e os desvios, consiste em um instrumento metodológico que permite verificar o constante trabalho de "remontagem" do social. Ou seja, para a teoria latourniana do "ator em rede", a controvérsia é um momento privilegiado de captura desse "social" instável, e dinâmico, ora instanciado - e que mais adiante pode assumir outras feições.

Para analisar a dinâmica dos argumentos nos diferentes momentos da controvérsia, lançarei mão do "dispositivo judiciário" forjado por Favret-Saada (1992) para pensar situações em que há uma acusação de blasfêmia em jogo. Em vez de analisar e avaliar em que medida algo é blasfematório per se, transfere-se o foco da questão para o arranjo no qual um denunciador aciona um determinado arsenal teológico para enquadrar uma fala, imagem ou representação, que passa então a ser considerada ofensiva. Nessa perspectiva, nenhuma mensagem é essencialmente blasfematória e o foco da investigação recai sobre o modo como o denunciador constrói a acusação e quais são os "lugares de enunciação" daqueles que têm autoridade para repreender e daqueles que são repreendidos (idem: 254). Amplio os limites do arranjo de Favret-Saada para além da blasfêmia, e assim, mais do que averiguar a medida da ofensa que a Igrejinha da Pampulha representou para os que a condenavam, analiso o modo como constroem
2 O material utilizado para a análise conta majoritariamente com matérias de jornais de circulação nacional e regional, revistas de variedades $\mathrm{e}$ especializadas (em arte, arquitetura, religião etc.), documentos e correspondências públicas, biografias das personagens envolvidas no debate entre outras fontes. Para uma contextualização pormenorizada da construção do corpus de dados, cf. Oliveira (2014). 
sua condenação a partir de um lugar de fala específico. O mesmo se aplica aos seus interlocutores que ora respondem a acusações, ora lançam novas críticas que alimentam a chama da controvérsia. Trata-se portanto de acompanhare analisar o debate em torno da recusa da consagração da Igrejinha da Pampulha a partir das elaborações de Giumbelli, Latour e Favret-Saada, entendendo que estes autores convergem e se complementam em suas diferentes abordagens processuais de episódios litigiosos da vida social.

O texto está organizado em quatro partes. Na primeira seção, apresento uma cartografia da controvérsia, caracterizando o seu estabelecimento e analisando os principais argumentos, personagens e posições em jogo. Em seguida, examino as especificidades do argumento religioso acerca dos imperativos para constituição de espaços religiosos e, em contraste, a construção da legitimidade artística e arquitetônica da Igrejinha da Pampulha, por parte de seus defensores. A terceira seção discute as condições que conduzem à consagração alternativa da Igrejinha como patrimônio nacional. Finalmente, através de um salto temporal, recupero o desfecho da controvérsia e apresento algumas sínteses interpretativas sobre o caso.

\section{A CONSTRUÇÃO DA CONTROVÉRSIA: ARGUMENTOS, PERSONAGENS E POSIÇõES}

O veredito do arcebispo de Belo Horizonte sobre a Igrejinha da Pampulha foi publicizado em uma entrevista concedida ao jornal carioca $A$ Noite ${ }^{3}$. Nesta ocasião, o religioso justifica sua posição principalmente em duas frentes. Em primeiro lugar, destaca a total alienação da Igreja Católica em relação ao projeto de Kubitschek e Niemeyer, sublinhando que "não foi feita a doação do terreno à paroquia nem foram apresentados planos para aprovação prévia". Diante da informação, o repórter insiste: "Mas não houve aprovação prévia?", ao que d. Cabral responde:

não, e nem foi solicitada. É uma obra inteiramente particular. Na qual o clero não teve a mínima participação. Minhas visitas foram feitas em caráter protocolar, pois não me poderia em absoluto excusar aos ouvintes. Aguardava entretanto que o interior da igreja não divergisse da tradição e do equilíbrio. Mas, como tempo, verifiquei, dolorosamente, que a fantasia dos artistas estava conduzindo por outros caminhos a realização de uma obra que se dizia em louvor ao piedoso São Francisco.

Do argumento inicial, opera-se um deslizamento para questões formais do espaço. $\mathrm{O}$ arcebispo se detém nesse ponto, fazendo comentários sobre sua arquitetura e decoração. Sobre o primeiro ponto, ele afirma:
3 "Condenada a Igreja de São Francisco da Pampulha". A Noite. Rio de Janeiro, 26 ago. 1945. Consultado no Memorial da Arquidiocese de Belo Horizonte, arquivo "Inventário da Igrejinha da Pampulha". 
Quanto ao estilo arquitetônico, repito, poderia haver tolerância. Na França, todas as construções religiosas estão obedecendo a técnica do cimento armado. Estilo verdadeiramente revolucionário, porém, compreensível. Torres parecidas com as das antenas das estações de rádio, encimadas pela cruz, e outras iniciativas, tornam esses templos moderníssimos, bonitos e práticos [...]. Porque aqui, não se tolerar o mesmo? Mas, de uma torre de antena, terminando com uma cruz, que bem simboliza a irradiação da fé, à essa da Pampulha, armada em sentido inverso, nada representando além de um bom cálculo de engenharia, há uma diferença enorme. Enquanto a primeira se atira ao alto, procurando a luz, bem elevando o símbolo sacrossanto da fé, a outra parece quever perfurar o solo, em busca das trevas...

Interpelado pelo jornalista sobre a decoração, ele continua:

Desgostaram profundamente o clero e os fiéis. Fantasias de artistas. Extravagâncias que podem ficar muito bem nos salões de arte; motivo para estudos, polêmicas e discussões entre artistas, jornalistas e escritores. Acredito que tanto os adeptos do modernismo como os defensores da arte antiga, do chamado academismo, estão com razão, pois todos lutam pela evolução artística. Mas, para um templo, aquilo não fica bem; não podemos desvirtuar a obra do Senhor nem a igreja é lugar para experiências materialistas, embora artísticas.

Para d. Cabral, a condução do projeto exclusivamente pelo político, o arquiteto e os artistas inviabiliza sua aceitação como um espaço legitimamente religioso. Além disso, as escolhas estéticas feitas por eles se alinham estritamente aos interesses dos artistas em disputa pela "evolução artística", colocando o resultado final - "extravagante" e "fantasioso" - na contramão do imperativo sagrado do recolhimento.

Anos mais tarde, quando da publicação de suas memórias, Juscelino Kubitschek dará sua versão para a recusa do arcebispo. Segundo o político, d. Cabral manifesta evidente "má vontade" ao receber seu convite para conhecer o projeto concluído. Conduzindo pessoalmente a visita, Kubitschek constata uma mudança positiva no ânimo do religioso diante dos edifícios do complexo arquitetônico da Pampulha. Entretanto, ao entrar na Igrejinha, o político conta que

Dom Cabral contemplou o mural de Portinari e tornou-se, subitamente, sombrio. Ignorou o batistério, a Via-sacra, o bronze de Ceschiatti, para concentrar-se na contemplação daquele suave São Francisco de Assis cuja figura irradiava tanto misticismo. Aproximou-se para examinar melhor. Voltando-se para mim, extravasou sua indignação: 'um cachorro atrás do altar, Sr. Prefeito. É inconcebível' (1976: 65). 
Kubitschek tenta explicar a iniciativa de Portinari de, segundo sua opinião, "nacionalizar" a afeição do santo pelos animais: "ao invés do lobo, um cachorro humilde, bem brasileiro" (idem). Porém, o arcebispo não consegue conter sua indignação: "um cachorro atrás do altar... Isso é um escárnio à Religião" (idem).

Enquanto, de um lado, d. Cabral defende o argumento de que a igreja não pode ser incorporada como espaço sagrado uma vez que sua construção se deu sob a chave do alheamento dos padrões religiosos (de regulação normativa e sobretudo estética); de outro, Juscelino Kubistchek alega uma predisposição negativa do religioso à acolher a igrejinha, fato que o teria levado a elencar a imagem do cachorro no altar como um pretexto para a condenação que já pretendia sentenciar.

A partir da recusa da consagração, estabelece-se um debate público entre diferentes atores sociais favoráveis e contrários à decisão do arcebispo, que se fizeram ouvir e replicar principalmente a partir de matérias em jornais e revistas. Como destaca Valérie Robert (2003), ao divulgar um debate, as diferentes mídias não somente o publicizam, mas no ato mesmo de representá-lo ajudam a construí-lo.

Uma cartografia dos argumentos em jogo na controvérsia aponta para uma divisão em duas frentes francamente conectadas às posições do arcebispo e do prefeito: de um lado, a alegação da sua inadequação para o serviço religioso; de outro, a defesa da sua condução às atividades religiosas para as quais foi planejada. Pode-se afirmar que boa parte das posições e argumentos lançados no debate adotavam uma ou outra posição. Há ainda uma terceira via na qual se enfileiram os argumentos e opiniões ambíguos que elogiam a qualidade arquitetônica e artística da Igrejinha, sem entretanto outorgar-lhe um valor sagrado.

Uma análise do conjunto das posições contrárias à consagração da Igrejinha da Pampulha indica que o argumento da inadequação do espaço para atividades religiosas se justifica sobretudo em três planos. Primeiramente, sustenta-se que a edificação teria sido um projeto externo à Igreja Católica sem se adequar às suas normas e regulações para construções de espaços religiosos. Em segundo lugar, sua expressão estética conteria uma extravagância característica da arte moderna e incompatível com o sentimento de introspecção que as construções sagradas deveriam evocar, no limite constituindo uma ofensa religiosa. 0 terceiro plano reprova a intencionalidade política tanto da agenda modernizadora de Juscelino Kubitschek quanto dos realizadores da Igrejinha, arquiteto e artista, condenados por seus vínculos com o comunismo.

Dentre os atores que lançam mão do argumento da inadequação da Igrejinha para uso religioso, o arcebispo de Belo Horizonte d. Antonio dos Santos Cabral se destaca. Ele se posiciona em algumas ocasiões e são seus, individualmente ou em nome da Cúria Metropolitana, os principais argumentos com que seus interlocutores dialogam. Há ainda alguns críticos, colunistas e jornais que 
contribuem com comentários e textos se alinhando à crítica à sagração da Igreja (e da sua construção). Dentre os mencionados neste artigo, estão o historiador e diretor do Instituto Histórico de Ouro Preto e do Museu de Arte e História da Casa de Gonzaga Vicente Racioppi; Padre Álvaro Negromonte, em texto para o Jornal do Brasil; David Nasser, da revista O Cruzeiro, e alguns textos não assinados veiculados nos jornais Tribuna da Imprensa, A Notícia, entre outros.

Do outro lado, as posições em defesa da utilização da igrejinha da Pampulha para o culto católico se ancoram em uma paleta de argumentos mais variada. $O$ mais recorrente é o de que a Igrejinha teria um valor intrinsecamente positivo por consistir em um experimento estético que revoluciona as bases da arquitetura brasileira (e em outra escala, mundial), modernizando-a e renovando (à reboque) a arquitetura religiosa. Complementar a este argumento é o da defesa de que ela estaria inserida no movimento mais amplo da evolução da arquitetura mundial, para o qual a Igreja Católica sempre colaborou com exemplares renovadores em períodos anteriores da história. Ainda em conexão com os dois primeiros argumentos está um terceiro, que emerge com o desenrolar da controvérsia, e diz respeito ao caráter icônico que a Igrejinha ganhou, permitindo projetar uma imagem positiva do Brasil como produtor cultural (e não somente consumidor) no cenário internacional. Em outro plano, um quarto argumento se baseia na sustentação da autonomia da arte (parcialmente abarcando a arquitetura) como dimensão independente e livre que possui seus próprios critérios de produção, que não devem atender a demandas de adaptação ou controle externos. Finalmente, o quinto argumento, e um dos mais frequentes, é o da fidelidade ao programa de uso arquitetônico concebido para a Igrejinha. Isto é, se a edificação fora pensada para ser uma igreja, ela não pode atender a outra finalidade senão essa.

Entre os defensores da sagração da Igrejinha para a realização de ofícios religiosos estão ]uscelino Kubitschek (que ao longo da controvérsia realiza uma trajetória de ascensão política do executivo municipal, ao estadual, finalmente chegando à presidência da República), mais timidamente seus realizadores, o arquiteto, Oscar Niemeyer, e o pintor, Candido Portinari. Alinhados nessa frente estão arquitetos como Sylvio Vasconcelos, Hardy Filho, Joaquim Cardozo, Lucio Costa, Luís Saia; escritores como Eduardo Frieiro; críticos de arte como Cermaine Bazin, Jaime Mauricio, Flávio de Aquino; e jornalistas tais como José C. Borba, Celso Kelly, Milton Pedrosa, entre outros da Folha Carioca, Diário de Notícias, Correio da Manhã e, sobretudo, o Estado de Minas. Este último publica uma série de reportagens no final dos anos de 1940 sobre a situação de abandono da Igrejinha da Pampulha e do conjunto arquitetônico como um todo.

O debate ganha corpo a partir desta disputa, mas não se fundamenta em defesas e reações partindo sempre dos mesmos atores sociais. Alguns se destacam 
por um engajamento mais perene, mas os dissensos, frequentemente irrompem e se alternam a consensos entre diferentes personagens que ganham alguma visibilidade momentânea para mais adiante os holofotes recaírem sobre outros. Alguns atores mudam, o debate permanece em torno da recusa ou aceitação da sagração da Igrejinha.

A contenda mantém seu fôlego durante quase quinze anos, com alguns momentos de arrefecimento até sua conclusão, com a tão esperada consagração oficial pela Igreja Católica. Nas próximas seções discuto a dinâmica dos principais argumentos em jogo nos primeiros anos da controvérsia, os quais forjaram os primeiros traços da "biografia cultural" (Koppytoff 1986) da Igrejinha da Pampulha.

\section{IGREJA OU MUSEU?}

Ainda à época da recusa da consagração da Igrejinha, o arcebispo belorizontino já colocara em pauta uma sugestão de finalidade alternativa para a edificação. Ele propõe $e^{4}$

Por que, ali, não se instala um museu de arte moderna? Essa luta toda está marcando uma época. Dentro em pouco, os artistas se ajustarão, encontrando os caminhos que procuram, e o período do combate passará. Aí, então, ninguém pensará em construir edifícios como aquele, porque a arte moderna já será outra... assim pois, é aconsel hável aproveitar a quase igreja de S. Francisco da Pampulha com toda a sua extravagância. Em vez desta discussão de agora, de toda essa divergência, contentaríamos uma corrente, não desgostando a outra, $e$ todos ficariam com o espírito tranquilo, uns servindo sua arte, outros trabalhando na seara do Senhor sem outra preocupação além de serem úteis.

Para d. Cabral, a "quase Igreja da Pampulha" constituiria um ícone de um momento de disputas na história da arte: o do "desvio modernista". Portanto, deveria cumprir uma função memorial para o futuro, como uma lembrança das rotas "extravagantes" trilhadas pela arte quando esta reencontrasse "seu caminho".

Ainda que seja evidente o sentido negativo atribuído pelo religioso às escoIhas estéticas encarnadas na Igrejinha-as inversões estruturais que "procuram as trevas", as "fantasias de artistas" que fogem dos ideais sagrados de equilíbrio e tradição - há o entendimento de que elas fazem parte de um movimento de "evolução artística". Trata-se de reconhecer a normalidade das disputas travadas dentro do campo artístico entre modernos e antigos através de "experiências materialistas" mais ou menos polêmicas. Desse modo, o problema seria menos as obras em si, mas antes a construção de um espaço que se pretende sagrado enquanto palco de experimentalismos estéticos disruptivos. Ou seja, misturar o
4 "Condenada a Igreja de São Francisco da Pampulha". A Noite. Rio de Janeiro, 26 ago. 1945. Consultado no Memorial da Arquidiocese de Belo Horizonte, arquivo "Inventário da Igrejinha da Pampulha". 
espaço sagrado à esfera artística.

A sugestão do arcebispo é uma "resposta" para o caso que contempla a complementaridade dos dois argumentos principais presentes na sua condenação religiosa da edificação: a inadequação para uso sagrado diante do al heamento da Igreja Católica no seu processo de elaboração; e o reconhecimento da exemplaridade dos experimentalismos estéticos nela atualizados. Enquanto este último argumento é pormenorizado por d. Cabral na entrevista, os detalhes sobre o primeiro vão aparecer em um texto de sua autoria publicado, no calor do debate, na revista belorizontina Arquitetura e Engenharia, em um dossiê dedicado à Igrejinha da Pampulha que traz "depoimentos de um arquiteto, um esteta, um intelectual e do arcebispo" (1946: 41). Ao reunir textos do arcebispo justificando sua condenação da igrejinha e de especialistas "contra-argumentando" em sua defesa, a publicação se torna um fragmento significativo do debate público em torno da consagração da Igrejinha da Pampulha.

Em seu texto, d. Cabral defende que, a despeito de sua "simpatia inicial" à ideia de se construir um templo "no novo e encantador recanto da Pampulha", as condições de sua implementação o levaram a ter reservas em relação ao projeto. O religioso menciona as reações negativas da população local que demonstraram "estranheza e murmurações" (1946: 44), cujos primeiros sinais levaram-no a procurar o então prefeito para manifestar suas restrições. Deste teria recebido a confirmação de que a edificação se submeteria às determinações eclesiásticas com o término das obras, quando então se poderia ter "uma visão de conjunto que permitisse um juízo seguro" (idem). Para d. Cabral, entretanto, o problema estaria ancorado em uma dissintonia jurídica decorrente do seu al heamento em relação ao projeto, expresso em sua alegação de que "não me foram apresentadas as plantas, como prescrevem as normas eclesiásticas, nem, tão pouco, recebeu a Mitra a doação dos terrenos, condição, 'sine qua', para se autorizar a construção de um templo destinado ao culto público" (idem: 44).

De acordo com Menezes (1962), as prescrições eclesiásticas para a construção de templos religioso vigentes naquele período encontram-se em dois documentos: no Código de Direito Canônico e nas Constituições Eclesiásticas do Brasil compiladas pela Pastoral Coletiva de 1915 . No primeiro, o cânon $1162^{5} \S 1^{\circ}$ afirma: "Não se podem edificar igrejas e capelas ou oratórios públicos para a celebração do santo sacrifício da Missa, sem permissão do Ordinário diocesano, por escrito" (apud Menezes, 1962: 23). O segundo documento é mais detalhado nesse sentido. O número 744 das Constituições Eclesiásticas do Brasil traz o seguinte texto:

Não daremos essa licença, nem permitiremos que se lance a primeira pedra do edificio, sem que se verifiquem as seguintes cláusulas: [...] $§ 5^{\circ}-$ Que se tenha apresentado a planta do edifício, com todos os delineamentos, para ser exami-

5 O Código de Direito Canônico vigente à época datava de 1917. Atualmente, após a reforma de 1983 , os cânons que versam sobre as edificações religiosas se estendem do 1214 ao 1229 Para acessar o atual Código de Direito Canônico, cf. http:// www.vatican.va/archive/codiuris-canonici/portuguese/ codex-iuris-canonici_po.pdf - Acessado em 27/04/13. 
nada e aprovada devidamente pelo Ordinário diocesano; §-Que se tenha obtido da cúria diocesana licença para bênção e lançamento da primeira pedra da igreja (Pastoral Coletiva apud Menezes, 1962: 24).

Neste caso, recorre-se portanto a uma legislação interna à Igreja Católica que garante seu direito ao estabelecimento e controle das edificações que serão utilizadas para suas atividades religiosas. Aqui o argumento do arcebispo se fundamenta na preservação dos critérios internos da Igreja, ou seja, sua separação em relação a outras esferas.

Reconduzindo o episódio para o contexto das relações entre Igreja Católica e Estado no Brasil, chamo a atenção para o fato do argumento da separação via especialização ser acionado do lado religioso. Trata-se de um período marcado pelo fim do regime de aliança com o Estado, separação alcançada por republicanos em contraposição aos interesses da Igreja Católica, ávida por manter seu status de religião oficial. Entretanto, como ressalta Giumbelli (2002a), a Igreja Católica mantém uma posição ambígua em relação ao tema, ora demandando o reconhecimento do papel fundamental da religião como garantidora da "prosperidade e da estabilidade de uma nação, de sua ordem e progresso" (idem: 253) - papel a ser desempenhado pelo catolicismo enquanto religião da maioria; ora, pleiteando autonomia, exortando aos 'homens de Estado[:] o que pertence à religião deixai-o sob a exclusiva alçada dos pastores da Igreja' (Pastoral 1890: 27 apud Giumbelli idem). Assim, "da reclamação contra a separação chegava-se ao desejo de liberdade" (idem). Mas a ambiguidade não se encerra aí, pois da mesma forma "é também possível fazer o trajeto inverso, do elogio à liberdade até a reivindicação de privilégios" (idem). Privilégios estes, como bem lembra o autor, que se refletem, entre outras instâncias, no lugar de interlocutor preferido do Estado quando do estabelecimento dos cânones que passam a regular as relações entre este e as religiões no Brasil. Ou seja, com o fim do regime, a Igreja Católica não se torna "mais uma" religião entre outras porque o Estado a toma como modelo (de religião) em relação a qual estabelece suas normatizações para reger diversas áreas da vida pública religiosa: regime de associação, de regulação de bens etc.

Um paralelo interessante para pensar as relações entre Igreja Católica e Estado em torno de uma edificação pode ser traçado com o episódio da construção do Monumento ao Cristo Redentor, no Rio de Janeiro, por iniciativa de intelectuais católicos e da hierarquia local. Para Ciumbelli (2008), o projeto constitui uma "resposta" católica de repúdio ao fim do padroado e a instalação da República. Ele é efeito ao mesmo tempo da liberdade religiosa assegurada pelo novo regime e do esforço da Igreja Católica para desfrutar de tal liberdade a partir de uma posição privilegiada de religião que representa a "verdadeira alma nacional 
nos quatro séculos da existência do Brasil" (Mensageiro do Sagrado Coração de Jesus apud Ciumbelli, 2011: 60). Neste caso, o recurso à ideia do Brasil como "país católico" se afina com o ideário republicano na medida em que apela ao princípio liberal e moderno de maioria.

Nesse contexto, não é de se estranhar que Kubitschek, ao propor um projeto de bairro novo para Belo Horizonte cogitasse uma edificação que desse conta da dimensão religiosa da população, e a pensasse católica, reforçando o status privilegiado de que a religião gozava. No mesmo sentido, se considerarmos sua iniciativa na chave de uma antropologia da modernidade, como proposta por Holston (1993), a introdução da dimensão religiosa no plano urbanístico da Pampulha se coaduna com o projeto de sociedade fomentado pelos modernistas, dentre os quais Kubitschek figura com proeminência. Esta nova sociedade, ancorada no ideário do Estado-nação moderno, é idealizada e edificada por autoridades políticas modernas, como o então prefeito belorizontino, engajadas na formulação de novas formas de esfera pública, novos sujeitos e subjetividades. Nesse projeto, a arquitetura emerge como um instrumento para a criação de novos modos de associação coletiva e hábitos pessoais, que devem contemplar desde a hospedagem, passando pelas práticas de lazer, esporte e mesmo a religião. $O$ cidadão moderno da cidade do futuro é pensado como o contemporâneo dos modernistas, dotado de fé, e que portanto precisa ter suas necessidades contempladas nas novas formas de habitar a cidade.

Mesmo compreendendo o papel da dimensão religiosa para o desenvolvimento do projeto de modernidade de Kubitschek, aqui também se pode apontar para a ambiguidade da posição do prefeito. Esta aparece na medida em que sua atuação ora se apresenta como vetor de intensa modernização política, cultural e social, alterando o plano urbano da cidade, associando-o a arquitetos e artistas modernos; ora inclui em seu programa um espaço religioso desconsiderando a dimensão da autonomia da Igreja Católica em deliberar sobre os ambientes dedicados às suas atividades.

Uma lembrança de Kubitschek ilumina a postura privilegiada do prelado católico, ajudando a compreender as relações entre o político e o arcebispo como alegoria das relações entre Estado e religião supramencionadas. Ele narra:

Em 1941, estava em construção um templo protestante na Praça Raul Soares. Certo dia, D. Antonio Cabral, arcebispo de Belo Horizonte, procurou-me para solicitar que embargasse a obra. O motivo alegado era que a ereção daquele templo, no centro da cidade, constituía ofensa ao sentimento religioso do povo de Belo Horizonte. Embora sendo, eu próprio, católico praticante, recusei-me a atender o pedido. Disse ao ilustre prelado que, por formação espiritual, sempre respeitara opiniões políticas e credos religiosos e que, na minha gestão a frente da 
Prefeitura, jamais tomaria qualquer atitude que importasse em impedimento ou mesmo em cerceamento da livre manifestação do pensamento em Belo Horizonte (Kubitschek, 1976: 33).

Neste caso, o arcebispo considera a construção de um templo de uma religião concorrente em uma praça pública ${ }^{6}$ uma ofensa recorrendo exatamente ao argumento da maioria latente na expressão "povo de Belo Horizonte". Pode-se inferir que a aparição de um templo de uma outra religião tenha causado incômodo ao arcebispo acostumado com a paisagem histórica e hegemonicamente marcada pelas construções de igrejas católicas. Esta novidade só foi possível com o estabelecimento da República, cuja Constituição de 1890 substitui a imperial de 1824 que, muito embora fosse favorável à liberdade religiosa, determinava em seu art.5b que: "todas as outras religiões serão permitidas com seu culto doméstico ou particular, em casas para isso destinadas, sem forma alguma exterior de templo" (apud Giumbelli, 2002a: 244). Ou seja, nos tempos em que a Igreja Católica era religião oficial podia-se aceitar tolerantemente a prática de outras religiões, desde que fossem realizadas na dimensão privada do espaço doméstico ou em outros, mas que não poderiam aludir externamente à ideia de templo, prerrogativa exclusiva da igreja romana. Além disso, se, de um lado, o arcebispo aglutinava o argumento religioso com um de ordem democrática, Kubitschek não fazia diferente: sua formação espiritual (de católico praticante) o teria forjado um respeitador das diferenças religiosas e portanto um democrata.

Quatro anos após esse episódio, foi a vez do arcebispo se recusar a abençoar o templo religioso planejado pelo prefeito. É difícil saber em que medida o caso influenciou a decisão de d. Cabral em relação à Igrejinha da Pampulha. Kubitschek evoca a ideia de uma antipatia inicial do religioso. D. Cabral por sua vez se fundamenta em um argumento legitimado na chave de leitura moderna das relações entre Estado e Igreja Católica. Entretanto, a dissintonia jurídica é apenas uma face da questão. A outra diz respeito às características formais da igreja. Grande parte do debate público se concentra neste ponto: arquitetos, artistas, críticos de arte, jornalistas, intelectuais etc., apresentam argumentos em contraposição à opinião do arcebispo procurando legitimar as opções formais de Niemeyer e de Portinari?.

Além do artigo de d. Cabral, o supramencionado dossiê da revista Arquitetura e Engenharia contou ainda com mais três textos sobre a Igrejinha da PampuIha. Tanto o artigo do arquiteto Raphael Hardy Filho, quanto o do "intelectual" (e também arquiteto) Sylvio Vasconcelos e o do crítico de arte francês Cermaine Bazin são abertamente elogiosos e legitimadores. Os três se aproximam na defesa do valor artístico e arquitetônico da Igrejinha, com argumentos fundamentados em dimensões distintas.
$6 \quad$ Não se trata de uma praça qualquer, mas a praça idealizada para sediar o 20 Congresso Eucarístico Nacional. Agradeço ao Prof. Ivo Porto Menezes pela informação e por ressaltar sua ligação com o desgosto do arcebispo em ver construído naquele local um templo protestante.

7 É interessante notar que no debate os outros artistas que participaram do plano decorativo são quase completamente ignorados. Paulo Werneck não chega a ser mencionado nem uma única vez nos jornais acessados. Alfredo Ceschiatti é citado em três dos 67 textos consultados. 
Concentrando-se nos aspectos formais da edificação, Hardy Filho analisa os principais traços de sua estrutura, a disposição dos volumes e elementos utilitários, para finalmente concluir que seu programa cumpre a proposta básica do templo religioso, qual seja, o de "cobrir o altar e os fieis" (1946: 42). Num registro mais amplo, para o arquiteto, a Igrejinha da Pampulha representa uma arquitetura que "sem abandonar os belos ensinamentos da tradição e sem se submeter, porém, a concepções retrógradas, deve caminhar para a frente” (idem).

Sylvio Vasconcelos (1946), por sua vez, sublinha o papel de vanguarda da arte desempenhado historicamente pela Igreja Católica, principalmente através da "agregação" de diferentes estilos artísticos advindos da "incorporação" de templos e obras de religiões alheias. Assim, Vasconcelos parece querer recordar um certo "passado profano" de quem agora pretende arrogar-se à bandeira de pureza da tradição. $O$ arquiteto destaca que o argumento chave que fundamenta grande parte das críticas estéticas contra a Igrejinha é a ideia de que a deformação operada por Niemeyer em geral e Portinari (particularmente no São Francisco) profana o espaço que se pretende sagrado. Sobre esse ponto, ele contra-argumenta em dois planos articulados.

O primeiro concentra-se na ideia de que o modernismo de Portinari não inaugura as experiências com a deformação. Essa é uma constante na história da arte, sobretudo na da Igreja Católica. Nesse sentido, Vasconcelos afirma: "se Rubens ou qualquer outro nos faz um cavalo com pernas de palitos está muito bem, senhores... porém, se Portinari os faz de pernas grossas, que calamidade!" (1946: 43). O que está em jogo é a sacralização da arte antiga manifesta no apego às formas do passado, mesmo que essas apresentem escolhas estéticas análogas às que se encontram na Pampulha.

O segundo, refere-se à constatação de que subjaz à crítica das deformações que estas na verdade constituem profanações comunistas de Niemeyer e Portinari contra a Igreja Católica. Nessa frente, Vasconcelos sugere que, seguindo tal raciocínio, Aleijadinho seria "nosso primeiro comunista. Aquelas deformações, o caricaturismo", "e as aureolas nas cabeças dos santos não são surrealismos?", ele pergunta (idem). Contra a acusação de que o modernismo de Portinari profana São Francisco através da deformação, ele afirma "só mesmo quem não pôde melhor examinar a história da arte, inclusive a hoje chamada acadêmica, pode imputar ao modernismo as deformações" (idem). O arquiteto se pergunta, no limite, se afinal São Francisco não seria mesmo comunista; e Cristo? Para finalmente concluir: “Onde está escondido o 'gatinho' do comunismo? Não estará apenas roendo os miolos de quem o descobriu?" (idem).

Bazin por sua vez compartilha da opinião de Vasconcelos a respeito do papel fundamental desempenhado pela Igreja Católica no desenvolvimento das artes, entretanto, identifica um movimento recente de adoção de uma “imaginária 
devota, de fraco, senão nulo valor de arte às criações autênticas duma arte viva" (1946: 17). Para o curador do Museu do Louvre, uma vez isolada de todo movimento mais geral da arte viva (de vanguarda), a arte católica se corrompe e se torna estéril-eternamente requentando os estilos (gloriosos) do passado e ao mesmo tempo tentando expurgar de sua imaginária "toda a humanidade e todo o patético" (idem).

Assim como Hardy Filho e, mais fortemente, Vasconcelos, Bazin lança mão do argumento do desapego aos estilos passados para justificar a defesa do valor estético e religioso da Igrejinha da Pampulha. O que atravessa seus argumentos é o reconhecimento do poder revitalizador da arte e arquitetura de vanguarda para a arte católica. Assim, Bazin resume o perigo da posição religiosa: "Separando-se da vida, recusando-se a participar deste mundo das formas perpetuamente renovadoras não se arriscará a Igreja a tornar-se uma sociedade fechada no interior da sociedade, a ver enfraquecida a sua catolicidade?" (idem: 17). Em outras palavras, o risco da iconoclastia não seria melhor do que a morte pela paralisação? Aliás, tratar-se-ia mesmo de um iconoclasmo conceder "feições modernas" a uma imagem devocional?

Sobre este ponto, Bruno Latour (2008) apresenta uma contribuição para pensar as reações que as imagens provocam, o que ele chama de "arqueologia do fanatismo". Para isso, ele elabora o conceito de iconoclash ${ }^{8}$. Diferentemente do iconoclasmo, quando o objetivo é claramente a destruição do objeto/imagem, "iconoclash, por outro lado, é quando não se sabe, quando se hesita, quando se é perturbado por uma ação para a qual não há maneira de saber, sem uma investigação maior, se é destrutiva ou construtiva" (2008: 113). Objetivando mapear as diferentes condutas em torno das imagens, Latour esboça uma tipologia de ações iconoclastas que vão desde os que odeiam todas as imagens aos que ironizam todos os odiadores e adoradores de imagens. Dentro deste espectro, ele descreve os iconoclastas do tipo B:

O que eles combatem é o congelamento das imagens, ou seja, extrair uma imagem do fluxo, e se tornar fascinado por ela, como se isso fosse suficiente, como se todo movimento tivesse parado. [...] Para eles, iconoclastas são ou aqueles que absurdamente tentam se livrar de todas as imagens, ou aqueles que permanecem na contemplação fascinada de uma imagem isolada, congelada (idem: 130-1).

Não seria esta a crítica de Bazin ao apego da Igreja Católica pelo passadismo e pelas imagens destituídas de humanidade? O congelamento em regras estáticas e desprovidas de pathos é rompido através de um certo dano feito à imagem romantizada do que deveria ser a arquitetura religiosa e a arte sacra?.

Duas intervenções no debate apresentam posições exemplares tanto do
$8 \quad$ Note-se que ao substituir o sufixo "asm" em iconoclasm para "clash" em iconoclash, Latour sublinha o caráter conflituoso derivado da ambiguidade das imagens em questão.

9 A participação de artistas modernos em projetos arquitetônicos e decorativos de igrejas católicas constituiu um movimento na primeira metade do século XX, no Brasil (Baptista, 1999; 2002) e também na Europa (Gamboni, 1997), principalmente na França (Caussé, 2010). Uma das principais censuras feitas por religiosos e críticos desses consórcios era a de que a arte vanguardista não continha sua tendência à "deformação" nem mesmo nas formas arquitetônicas, pinturas e esculturas religiosas. Em minha tese de doutorado (2014) comparo o caso da Igrejinha da Pampulha com o da Capela de Vence, situada no sul da França, idealizada em sua arquitetura e decoração pelo artista moderno Henri Matisse. Tanto Portinari quanto Matisse são acusados, entre outras coisas, de distorcer os padrões das formas clássicas consagrados na Igreja Católica, contra o que se defendem não somente reafirmando a liberdade dos seus (diferentes) estilos artísticos, mas sublinhando as relações entre o resultado da obra e os estados subjetivos ora dos "dramas" representados, ora dos artistas em seu momento de criação. Par maiores detalhes, cf. Oliveira (2014). 
apego a uma imagem nostálgica e adocicada da arte religiosa pretérita, quanto da iniciativa de sua renovação via danificação. A primeira é a do escritor e diretor do Instituto Histórico de Ouro Preto, Vicente Racioppi ${ }^{10}$ :

O templo católico não recebeu a inspiração religiosa que maravilha o mundo com as catedrais de Reims e Milão, de Colônia e Ouro Preto, de S. Joao del Rey e Mariana, da Bahia e do Rio de Janeiro, de Roma e de Varsóvia. Concebida e influenciada de maneira a matar a tradição arquitetônica mineira, adulterando tudo, inchando a perna de S. Francisco, Ihe entumecendo os músculos, Ihe arregalando os olhos e aviltando as meigas figuras dos santos, cuja doçura os pincéis dos pintores e o escopro dos escultores fixaram em poemas de arte eterna.

Em outra frente, a segunda intervenção é de Portinari. Perguntado se achava que o clero aceitaria suas pinturas sacras para a Igrejinha da Pampulha, o artista teria respondido ${ }^{11}$ :

Não! Os nossos padres não poderão gostar da minh a maneira de expressar as coisas sagradas. Eles querem figuras bem feitinhas, virgens parecidas com Ingrid Bergman e Cristos semelhantes a Robert Taylor. Essa é a verdade. Mas a minha "Via Sacra" para a Pampulha não tem nada disso. São João se alimentava de gafanhotos, Lázaro era leproso e Magdalena uma pecadora... tudo isso me inspira sentimentos múltiplos, as vezes tão extravagantes quanto a própria tragédia de São João. Enfim, comigo santo é santo mesmo, não é artista de Hollywood.

Também Bazin, em seu artigo supracitado, reconhece no São Francisco de Portinari na Pampulha as características de um personagem mais "profético do que seráfico", sobre o qual afirma: "brotando do deserto onde se alimentou de gafanhotos, esse asceta hirsuto, esse louco de Deus liberta com seus gestos veementes as forças encadeadas da natureza" (idem: 18).

Portinari e Bazin destacam o excesso de sofrimento e a miséria que marcam as diferentes histórias de vida das figuras santas retratadas. O dano aparece como uma espécie de atualização daquele excesso de humanidade. Nas palavras de Latour, "o dano feito aos ícones é, para eles, sempre uma injunção caridosa para redirecionar a atenção para outras imagens sagradas, mais novas, mais frescas [...]" (idem: 131). Para o diretor do Instituto Histórico de Outro Preto, inspiração divina é aquela oriunda das (congeladas?) igrejas góticas europeias e barrocas brasileiras. Mas onde Racioppi vê ruptura, outros veem continuidade.

Estendendo a aproximação estabelecida por Vasconcelos entre Portinari e Aleijadinho, Bazin considera que a arquitetura audaciosa e surpreendente de Niemeyer, embora inspirada nos princípios de Le Corbusier, vincula-se direta-
10 "A S. Francisco da Pampulha significa a hipertrofia de uma política artística derrotista". Revista Carioca. Rio de Janeiro, 21 set. 1946 Consultado no Memorial da Arquidiocese de Belo Horizonte, arquivo "Inventário da Igrejinha da Pampulha".

11 "Caipira, porém Portinari.... Revista O Clobo. Porto Alegre, 22 jun. 1946. Consultado no Memorial da Arquidiocese de Belo Horizonte, arquivo "Inventário da Igrejinha da Pampulha". 
mente ao "gênio barroco, [...] gênio autóctone da arte brasileira obscurecido há mais de um século pela influência neoclássica, e que, com Portinari e Niemeyer, acaba de experimentar sua revivescência magnífica" (idem: 18).

Enquanto d. Cabral mantem sua recusa em consagrar a Igrejinha da Pampulha fundamentado em argumentos jurídicos e estéticos, artistas e críticos se concentram nestes últimos, contra-argumentando no sentido de legitimar seu valor artístico e arquitetônico. Ao mesmo tempo em que desconsideram os argumentos de ordem jurídica, acabam por estruturar as bases de uma consagração alternativa àquela religiosa.

\section{UMA CONSAGRAÇÃO VIA PATRIMÔNIO}

A construção de uma conexão direta entre a arquitetura modernista precursora de Niemeyer e o barroco foi um caminho alternativo ao argumento de que a Igrejinha da Pampulha seria uma profanação da arquitetura e arte sacra brasileiras. Caminho dos mais eficientes, permitiu que, diante do vácuo institucional que se estabeleceu a partir da não utilização da igrejinha para serviços religiosos, e dos rumores de que poderia ser demolida, ela se tornasse um bem tombado pelo então Serviço do Patrimônio Histórico e Artístico Nacional, apenas dois anos após sua conclusão, atendendo a um parecer de Lucio Costa. Seu conteúdo professa $^{12}$ :

Considerando o estado de ruína precoce em que se encontra a Igreja de São Francisco de Assis, da Pampulha, em Belo Horizonte, devido a certos defeitos de construção e ao abandono a que foi relegado esse edifício pelas autoridades municipais e eclesiásticas; considerando que numerosas peças integrantes desse edificio destinado a capela, tais como altar, órgão, bancos, via sacra, etc., foram irresponsavelmente abandonados ou utilizados em outras igrejas de modo inconveniente, porque em desacordo com seu estilo peculiar; considerando o louvor unânime despertado por essa obra nos centros de maior responsabilidade artística e cultural do mundo inteiro, particularmente da Europa e dos Estados Unidos; considerando, enfim, que o valor excepcional desse monumento o destina a ser inscrito, mais cedo ou mais tarde, nos Livros do Tombo, como monumento nacional, e que portanto seria criminoso vê-lo arruinar-se por falta de medidas oportunas de preservação, para se haver de intervir mais tarde no sentido de uma restauração difícil e onerosa, tenho a honra de propor [...] o tombamento preventivo da Igreja de São Francisco de Assis, da Pampulha [...].

O parecer de Lucio Costa apresenta argumentos em dois planos principais, que poderiam ser descritos como o da imanência e o da transcendência. No primeiro
12 Parecer datando de 08/10/47 integra o Processo de Tombamento da Igreja de São Francisco de Assis da Pampulha, no. 373-T-47, de iniciativa do próprio SPHAN, p. 1. 
plano, estão os que dizem respeito à necessidade de preservar sua materialidade tanto do abandono quanto da descaracterização dos seus atributos. Em segundo lugar, aparecem os que the atribuem um valor simbólico reconhecido positivamente no plano internacional, cujo reflexo no âmbito nacional-em termos de tombamento enquanto monumento-seria considerado inevitável.

Em linhas gerais, é o acionamento da "retórica da perda" (Conçalves, 1996) iminente do bem que justifica sua consagração como patrimônio. Entretanto, como bem sublinha Choay (2006), a patrimonialização de um bem recente, no limite, descarta o próprio objeto do patrimônio, ou seja, o passado usufruído e acumulado em sua materialidade. Em outra chave, pode-se defender que o tombamento da Igrejinha da Pampulha encarne uma reconsideração - e não um descarte - do fator temporal através da conexão com a linhagem barroca. Embora a referência ao barroco não seja explícita no parecer de Lucio Costa, ela aparece em várias falas de outros interlocutores. Mesmo Costa a aciona, em outra ocasião, quando, respondendo à acusação de um suíço de que o projeto da Pampulha constituiria um "barroquismo escultórico", afirma: "Ora graças, pois se trata no caso de um barroquismo de legítima e pura filiação nativa que bem mostra não descendermos de relojoeiros, mas de fabricantes de igrejas barrocas" (1953: 183-184).

O contra-ataque de artistas, críticos de arte e arquitetos às críticas estéticas de d. Cabral à Igrejinha da Pampulha se conecta a um movimento mais amplo de institucionalização de um ideário de patrimônio nacional baseado na combinação de matrizes específicos de tradição e modernidade, no caso em tela, o barroco mineiro e a arquitetura moderna. Chuva explicita o processo de consolidação desse ideário ao afirmar que
Aparel hados no Sphan, os arquitetos modernistas consagraram a própria ar- quitetura que produziam, seguindo essa linha de pensamento como aquela que efetivamente representaria a nação moderna. Construíram, assim, simbólica e materialmente, o patrimônio histórico e artístico nacional mediante a eleição da arquitetura barroca colonial e a sua restauração. E, na repetição, consagra- ram-se na ordem inversa, construindo materialmente a arquitetura moderna e elegendo-a simbolicamente como patrimônio histórico e artístico nacional (2009:364).

$O$ arranjo aqui em jogo combina barroco e arquitetura modernista, em detrimento de quaisquer outros estilos atualizados em solo nacional. Através de um procedimento de purificação, excluem-se da história da arquitetura brasileira as manifestações nas quais não se identificava um germe de originalidade, reconhecido na Pampulha. Somente o novo e original, conectado à tradição, poderia constituir 
uma contribuição efetiva para a evolução da arquitetura nacional. Filiar a Igrejinha da Pampulha ao barroco significa portanto contaminá-la com a autenticidade modelar da identidade artística nacional, reconhecendo nela, ao mesmo tempo, um papel importante na continuidade do desenvolvimento da arquitetura.

Houve, do outro lado, quem discordasse dessa história da arquitetura brasileira, sobretudo neste capítulo em que se tentava introduzir a Igrejinha da PampuIha como bem de valor nacional, digno de tombamento. Um artigo publicado no Jornal A Notícia chama de "maluquice" o título de patrimônio histórico concedido à "famosa igreja futurista da Pampulha"13. Seu argumento se fundamenta no caráter ofensivo e escandaloso da edificação, considerada "um achincalhe à religião". Destaca-se que, diante desse quadro, o único destino "compatível com sua finalidade" seria torna-se "museu de arte teratológica", como teria sugerido o arcebispo. Diferentemente da ideia de exemplaridade, aqui a Igrejinha aparece como um

fantasma de cimento armado ostentando as suas formas grosseiras e servindo de demonstração do pouco caso dado aos dinheiros do povo, pois a pilhéria de mau gosto custará à municipalidade da capital mineira alguns milhões de cruzeiros. (idem)

Longe de constituir uma exemplaridade positiva, tratava-se de uma piada cara e de mau gosto, que deveria se contentar com o único papel que poderia desempenhar: o de museu de monstruosidades.

Muito embora parecesse para os defensores da Igrejinha que o tombamento constituísse, além do reconhecimento da sua singularidade e originalidade, a garantia para sua sobrevivência diante do abandono, isso se mostrou duvidoso. A incerteza se confirma no final do ano de 1948, quando o jornal Estado de Minas faz uma série de reportagens para denunciar o abandono que ameaçava a integridade física da Igrejinha. Em vários textos, o tom apologético vangloria a iniciativa de Kubitschek como "homem de bom gosto" e sua iniciativa de construir na Pampulha "um testemunho vivo da nossa época através do depoimento incontestável dos artistas contemporâneos"14. O recurso a elogios e falas legitimadoras embasa a construção e reforço do valor artístico e cultural de um bem sob ameaça de extinção.

Uma das personagens elencadas, o escritor mineiro Eduardo Frieiro, defende ${ }^{15}$ que o abandono é resultado de dois "boycotts". O primeiro deles seria o da Igreja Católica que, por "simples relutância [...] em face do novo e do nunca visto" "tentou desnaturalizar o caráter original da Igreja da Pampulha, tornando-a museu de arte moderna". O segundo seria de ordem política, decorrendo do fato de que apesar de todas as suas qualidades, a Igrejinha "padece de um defeito de origem: foi obra de outro". Para Frieiro, à sabotagem inicial da Igreja Católica é somada outra de ordem política, gerando o quadro de abandono que acomete
13 "Maluquice, Patrimônio Histórico...". A Notícia. Rio de Janeiro, 6 jul. 1948. Consultado no Memorial da Arquidiocese de Belo Horizonte, arquivo "Inventário da Igrejinha da Pampulha”.

\footnotetext{
14 "A Pampulha está inteiramente abandonada". Estado de Minas. Belo Horizonte, 9 dez. 1948. Consultado na Hemeroteca Municipal de Belo Horizonte.

15 "Aplaudido escritor
mineiro opina sobre as
condições da cidade-
satélite". Estado de Minas.
Belo Horizonte, 11 dez. 1948.
Consultado no Memorial
da Arquidiocese de Belo
Horizonte, arquivo "Inventário
da Igrejinha da Pampulha".
}


a edificação. O escritor mineiro evidencia que num contexto onde Kubitschek não é mais prefeito, o valor artístico e arquitetônico da Igrejinha, sua "genealogia barroca", pouco importa, já que no jogo político, a filiação que realmente garante a sobrevivência é a da "situação".

Eis que Kubitschek então se manifesta, fazendo publicar uma longa carta ${ }^{16}$ que enviara recentemente a $d$. Cabral, na qual solicita mais uma vez a reconsideração do arcebispo sobre a Igrejinha da Pampulha. Nela, o ex-prefeito belorizontino defende as motivações verdadeiramente puras e cristãs que o levaram a pensar em construir uma igreja na Pampulha, voltado unicamente para o objetivo de "proporcionar aos moradores do bairro cujo progresso desejava, uma assistência religiosa que a distância da cidade tornava muito difícil". Em seguida, enfileira uma série de argumentos favoráveis à Igrejinha e que já circulam no debate mais amplo: o papel histórico da Igreja Católica no desenvolvimento das artes, o reconhecimento nacional e internacional do valor cultural da edificação, suas características físicas conformes às necessidades litúrgicas entre outros. Finalmente, Kubitschek faz ao arcebispo "um apelo humilde no sentido de permitir que o pequeno e lindo templo se integrasse na sua missão".

As palavras do ex-prefeito porém não sensibilizam o religioso-pelo menos não por enquanto-, e a igrejinha continua silenciosamente fechada por mais uma década protagonizando outras fases de sua trajetória controversa ${ }^{17}$.

\section{DESENLACES DE UMA TRAMA}

A Igrejinha da Pampulha é finalmente consagrada em abril de 1959. A mudança de posição da Igreja Católica no caso pode ser apreendida em múltiplos planos, mas gostaria de sublinhar dois. O primeiro diz respeito aos argumentos levantados por seu responsável, o novo arcebispo belorizontino, $d$. Resende Costa, para justificar publicamente sua decisão. $O$ segundo se refere à articulação orquestrada por Kubitschek nos bastidores para tentar resolver o caso. Começando por este último, o então presidente da República conta que, naquele ano de 1959, após a designação de d. Resende Costa para ocupar o cargo de arcebispo coadjutor de Belo Horizonte - dada a debilitação do estado de saúde de d. Cabral -, decide promover um encontro com o novo responsável curial para tratar do caso da Igrejinha. Em suas palavras, "Dom Resende Costa revelou-se profundamente compreensivo e vinte quatro horas mais tarde procurou-me para me dar uma resposta definitiva a respeito" (1976: 65). A resposta era positiva, com a "sugestão" de que a prefeitura doasse o templo para a Mitra Arquidiocesana.

O projeto de lei autorizando a doação da Igrejinha é proposto pelo executivo municipal, aprovado pela câmara e sancionado em 6 de fevereiro de $1959^{18}$. O texto da lei é sucinto, dispondo de três artigos, dois dos quais cito a seguir:
16 "Um apelo do Sr. Juscelino Kubitschek para que a Igreja da Pampulha se integre em sua missão". Estado de Minas. Belo Horizonte, 15 dez. 1948 Consultado na Hemeroteca Municipal de Belo Horizonte.

17 A análise deste período do debate público e dos acontecimentos envolvendo a Igrejinha da Pampulha se encontra no segundo capítulo da minha tese de doutorado (Oliveira, 2014).

18 O texto da lei está disponível no site da Câmara Municipal de Belo Horizonte. Link: http://www.cmbh.mg.gov. br/leis/legislacao - acessado em 2/08/13. Agradeço à professora Monica Fonseca por ter primeiramente me chamado a atenção e me apresentado o conteúdo da lei. 
Artigo $2^{\circ}-A$ Mitra Arquidiocesana de Belo Horizonte, obriga-se a manter e a zelar pela conservação do imóvel, não lhe introduzindo modificação alguma na parte arquitetônica, nas pinturas e painéis internos e externos, sem autorização da Diretoria do Patrimônio Histórico e Artístico Nacional do Ministério da Educação e Cultura, bem como a observar as obrigações decorrentes de patrimônio tombado [...];

Artigo $3^{\circ}$ - a doação a que se refere a presente lei é gravada com as cláusulas de inalienabilidades, impenhorabilidade e de reversão ao domínio do Município na hipótese da dona tária não cumprir o disposto no art. $2^{\circ}$ ou destinar o imóvel para a finalidades diferentes do culto ca tólico, apostólico e romano, a que se destina.

O texto da lei evidencia a preocupação em regular os termos em que seria feita a passagem da Igrejinha das mãos do município para a Cúria Metropolitana de Belo Horizonte. É provável que seus idealizadores tivessem em mente a experiência do passado recente, quando, de posse de algum nível de comando sobre a edificação, a Igreja Católica dispõe do seu mobiliário distribuindo-o para outras paróquias, igrejas, capelas etc., sem entretanto pretender utilizá-la como espaço religioso ${ }^{19}$. As condições da doação são principalmente de duas ordens: proibindo a alteração de qualquer característica estética ou estrutural da Igrejinha sem a autorização prévia do órgão local responsável pelo patrimônio nacional; proibindo a sua utilização para qualquer outra finalidade que não seja o culto "católico, apostólico e romano" (idem). Ao estabelecer os modos específicos em que a Igreja Católica deve usar e se apropriar da Igrejinha da Pampulha, a legislação municipal atua explicitamente como um dispositivo de regulação do religioso (Giumbelli, 2002a). Isto porque com o objetivo de garantir a manutenção das suas características estéticas e estruturais, a legislação atua controlando o nível de autonomia religiosa para eventualmente imprimir no espaço transformações litúrgicas, eclesiásticas etc. Da mesma forma, a vinculação direta do direito à propriedade à utilização para culto "católico, apostólico, romano" (idem) estabelece a modalidade do culto privilegiando a vertente romana em detrimento de mudanças contingentes que porventura conduzam à constituição de uma Igreja Católica brasileira distanciada dos interesses romanos. Assim, consolida-se um mecanismo de enredamento entre o Estado e a Igreja Católica romana no qual o primeiro não só reconhece o culto religioso, como o reverencia e se coloca na posição de seu "avalista" para determinar que possíveis desvios impliquem em retorno da propriedade da Igrejinha ao município. Com tais medidas, a prática religiosa na capela é cerceada e condicionada às determinações legais; em outras palavras, trata-se de uma intervenção direta do Estado no domínio religioso.

Sobre os argumentos de d. Resende Costa para justificar a mudança de posi-
19 Esta informação é sugerida e aludida em diversas fontes. De forma sistemática aparece em cartas trocadas entre o diretor do Museu Histórico Abílio Barreto, Mário Lúcio Brandão, e o diretor do Departamento Municipal de Educação e Cultura. 
ção da Igreja Católica em relação à Igrejinha, eles aparecem em uma entrevista concedida à Folha da Manhã ${ }^{20}$ :

Hoje, desde que foram sanadas as irregularidades canônicas e estão tendo geral aceitação as novas expressões de arte a princípio tão chocantes, não há mais motivos para manter-se o veto oposto na ocasião pelo arcebispo d. Antonio dos Santos Cabral à igreja de São Francisco.

Do ponto de vista das suas características formais, o religioso comenta ainda que, embora considere "a nobre severidade do estilo clássico" mais adequada à Igreja Católica - por suas dimensões de "eternidade" - reconhece que a Igrejinha possui todos os elementos arquitetônicos necessários para o exercício do culto (idem). Já a pintura de Portinari-embora "excelente" - "corresponde menos bem à finalidade pedagógica que a Igreja exige nas decorações de arte" (idem).

A construção da argumentação endossa a ideia de que a passagem da propriedade da Igrejinha e do seu terreno à Cúria Metropolitana "sanou irregularidades canônicas", permitindo que se deslocasse para a observação mais geral da aceitação da arte moderna nos contextos religiosos. Destaque-se que nos documentos que regulam a construção de templos religiosos consultados ${ }^{21}$ não aparece a obrigatoriedade de posse da edificação religiosa e do terreno por parte da Igreja Católica para a realização da consagração e autorização para celebração de atividades religiosas. Tomando o relato de Kubitschek, pode-se aventar que a proposta de doação apresentada por $\mathrm{d}$. Resende Costa tivera a intenção de sinalizar um primeiro gesto de reverência do poder executivo municipal em relação ao qual a Igreja Católica poderia manifestar sua boavontade para rever o caso, inaugurando uma nova fase nas negociações. Em relação aos comentários estéticos de $\mathrm{D}$. Resende Costa, note-se que a distinção entre a arquitetura "adequada" de Niemeyer versus os "excelentes" e "inadequados" painéis de Portinari indicam ao mesmo tempo uma abertura para as novas interpretações da arte religiosa desenvolvidas com o viés modernista, e uma simpatia ao viés tradicional da função pedagógica da arte sacra.

A repercussão da consagração da Igrejinha da Pampulha na mídia se caracteriza pela "recordação" dos motivos da recusa inicial da Igreja Católica, sublinhando tanto seus aspectos formais quanto o perfil do espaço no qual ela estava inserida. Em outras palavras, "integrada num conjunto construído em função do vício e do pecado, o arcebispo não autorizou a sagração da capelinha, entre Cassino e Casa de Baile"22. O argumento que equaciona o Conjunto Arquitetônico da Pampulha ao profano e consequentemente à inviabilidade da existência de um espaço sagrado trabal ha na lógica da contaminação, que vai aos poucos se amenizando na medida em que o vetor de contágio se enfraquece até desapare-
20 "Finalmente, após muita discussão, será sagrada a Igreja da Pampulha". Folha da Manhã. São Paulo, 01 abr. 1959. Consultado no Memorial da Arquidiocese de Belo Horizonte, arquivo "Inventário da Igrejinha da Pampulha"

21 Código de Direito Canônico, \$1214 ao 1229: Constituições Eclesiásticas do Brasil, Pastoral Coletiva de 1915, n. 744, cf. Menezes 1962.

22 "Hoje o fim do mais rumoroso caso que envolveu a arte moderna no Brasil". Diário de Minas. Belo Horizonte, 11 abr. 1959. Consultado no Memorial da Arquidiocese de Belo Horizonte, arquivo "Inventário da Igrejinha da Pampulha". 
cer. Esta lógica fica evidente no excerto da matéria publicada no Estado de Minas no dia seguinte à cerimônia de consagração $0^{23}$ :

O veto da Igreja resultava menos de certas exigências de ordem arquitetônica que o templo não preenchia, do que do próprio bairro da Pampulha, à época sede de um cassino e de algumas boites. Faltavam, portanto, condições ao local para a presença de Deus conforme a bem fundamentada argumentação do arcebispo $d$. Cabral. Acontece porém que com a proibição do jogo e o fechamento do cassino e das boites, o ambiente na Pampulha é agora outro e a Igreja se dispôs com o seu velho equilíbrio e bom senso, a reexaminar o caso.

Ao conectar a condenação da Igrejinha ao seu entorno enquanto vetor de profanação que obstruiria a presença de Deus, as autoridades eclesiásticas deslocam o foco das suas características estéticas - imutáveis ainda que mais "aceitáveis" - para algo passível de transformação exógena: o ambiente social no qual ela se situa. Menos do que ter a necessidade de justificar a revisão dos seus próprios critérios estéticos basta-lhes constatar as transformações externas que agora liberam o espaço para o afloramento da presença de Deus. Mesmo do ponto de vista dos critérios estéticos da Igreja, $\mathrm{d}$. Resende Costa defende, durante a missa que precede a cerimônia de consagração da Igrejinha ${ }^{24}$, que a demora em sagrá-la se deve ao fato de que "a Igreja, que é mensageira da eternidade, não costuma ter pressa em aceitar as coisas de vanguarda”. Assim, a consagração da Igrejinha da Pampulha após quatorze anos não aparece como a revogação da decisão de d. Cabral, mas a remodelação de um arranjo no qual desaparecem as razões que motivaram a decisão inicial. Tanto é assim que, um mês mais tarde, d. Resende Costa sustenta conforme reportagem da revista Alterosa ${ }^{25}$ que

na época, estivesse ele no lugar de D. Cabral, teria agido da mesma forma, porque, na verdade, o templo apresentava características demasiado avançadas, em relação à arquitetura religiosa. 'Ademais - acrescentou-naquele tempo a Pampulha era apenas um bairro mundano. Agora, porém, muita gente vive, lá, e essa gente não poderia ficar sem a sua igreja.

A Pampulha deixa de ser frequentada por jogadores, notívagos e boêmios para se tornar um bairro habitado por moradores e visitantes do novo Museu de Arte da Pampulha instalado no antigo Cassino e das outras edificações do complexo. A conversão do espaço interpretada positivamente pela Igreja Católica também acarretou em um abandono físico da Igrejinha agravando permanentemente seu risco de arruinamento. Risco aliás que garantiu sua primeira consagração, aquela homologada quando do seu tombamento precoce como patrimônio
23 "A Sagração de um templo famoso". Estado de Minas. Belo Horizonte, 12 abr. 1959 Consultado na Hemeroteca Municipal de Belo Horizonte.

24 "Igreja da Pampulha tornou-se finalmente um templo de Deus". Diário de Minas. Belo Horizonte, 12 abr. 1959. Consultado na Hemeroteca Municipal de Belo Horizonte.

25 "Igrejinha da Pampulha já é casa de Deus". Alterosa. Belo Horizonte, ano V, n. 4 , setembro de 1959, p. 93. 
nacional. Esta consagração vinculada à administração do seu arruinamento potencial se ampliou e perpetuou no tempo concedendo visibilidade à Igrejinha enquanto "curiosidade artística e ponto obrigatório para todos os turistas que visitavam Belo Horizonte"26.

Consagrada enquanto patrimônio do Estado, pela crítica nacional e internacional, pelos turistas amantes da arte e da arquitetura - e mesmo pelos religiosos que a visitavam - finalmente logra ganhar a consagração da Igreja Católica. Diante de tamanha visibilidade e sucesso, sugiro que, além das transformações apontadas por $\mathrm{d}$. Resende Costa relativas à maior aceitação da arte moderna nos ambientes religiosos e a conversão do bairro da Pampulha, tenha havido uma ponderação de outra ordem para a deliberação favorável à consagração. Esta envolveria uma reavaliação das consequências políticas, sociais e culturais de manter o veredito adotado no final da década anterior. Àquela época, um arcebispo recusar o projeto de um prefeito desenvolvido por um arquiteto praticamente estreante e um artista moderno tinha um custo bem diferente do que manter, no final dos anos de 1950, a recusa à uma Igreja imaginada pelo atual presidente da república, realizada por um arquiteto reconhecido internacionalmente e idealizador da arquitetura da nova capital do país, e um artista moderno no auge da sua carreira. Mesmo do ponto de vista da Igrejinha, como já foi dito, ela deixa de ser o simples resultado de um exercício de experimentalismo para se tornar um símbolo da arquitetura moderna mundial e objeto de interesse e apreço da população local, que prestigia sua cerimônia.

O debate em torno da igrejinha da Pampulha constitui uma controvérsia entre diferentes atores em um contexto mais amplo de modernização social e urbana. Contrariando expectativas secularizantes de enxugamento da dimensão religiosa, o empreendimento modernizante da Pampulha idealizado por um político e desenvolvido por um arquiteto e um artista propõe incluir a dimensão religiosa. Nesse sentido, as reflexões de Giumbelli (2002) e Asad (1993; 2003) abordam a modernidade mais como um projeto ${ }^{27}$ do que como um estágio de desenvolvimento da civilização onde aspirações "transcendentais" e "mágicas" perdem relevância para perspectivas "tecnológicas" e "progressistas". No projeto "hegemônico" de modernidade, as políticas seculares dos Estados nacionais desempenham papel central, não somente por restringirem o espaço de atuação das religiões, mas também por constituírem práticas de relação e definição do religioso uma vez que

para proteger a política da religião (e especialmente alguns tipos de compor-
26 "Igreja de São Francisco torna-se 'Hangar de Deus'". Diário da Noite. Rio de Janeiro, 16 set. 1959 Consultado no Memorial da Arquidiocese de Belo Horizonte, arquivo "Inventário da Igrejinha da Pampulha”.

27 Holston (1993) também aposta nessa abordagem da modernidade como projeto, ou melhor, projetos em disputa que encarnam um dilema: 0 paradoxo de que a prática da construção desse futuro no presente acaba subvertendo suas premissas utópicas. Entretanto, a dimensão religiosa está distante de suas principais preocupações, que se concentram nas formações urbanas e arquitetônicas. 
tamento religiosamente motivados), para determinar suas formas aceitáveis dentro da política, o Estado precisa identificar a 'religião'. Ao ponto em que este trabalho de identificação se torna uma questão de lei, a República adquire a função teológica de definir os sinais religiosos e o poder de impor tal definição a seus cidadãos, 'assimilando-os' (Asad, 2006: 524).

O que poderia ser mais exemplar deste trabalho de definição do religioso do que o Estado, na figura de uma personagem política, tomar para si a iniciativa de projetar um espaço para realização de atividades especificamente religiosas, como no caso da Igrejinha da Pampulha? Note-se que temos aí um programa de definição "do religioso" que passa ao largo de uma associação explícita com o catolicismo institucional. Ou seja, a Igrejinha da Pampulha constitui ao mesmo tempo um projeto de modernização social amparado na dimensão religiosa como também um projeto de modernização religiosa, consorciado pelo Estado por meio da arquitetura e arte de vanguarda.

A reação católica, condensada na figura do arcebispo belorizontino, é a de recusar a "oferenda moderna". Fabris (2000) divide os argumentos de d. Cabral em duas ordens: um jurídico, em referência ao caráter "particular" da obra; e outro religioso, em defesa da tradição da estética católica contra o modernismo. Em outra chave, ambos os argumentos consistem em faces de um procedimento mais amplo de distinção entre o que seria propriamente religioso, de um lado, e de outro o que seria do âmbito da iniciativa "privada" (assim designado pelo religioso, porém correspondendo ao poder público) e da esfera artística. Em outras palavras, o argumento de $d$. Cabral possui um viés moderno ao distinguir a dimensão religiosa das investidas políticas e artísticas do projeto modernista de Juscelino Kubitschek. Como fica explícito no relacionamento prévio entre prefeito e arcebispo, a modernidade do argumento do religioso no caso da Pampulha, porém, não descarta a possibilidade de acionamento eventual de privilégios em nome dos interesses católicos da "maioria da população mineira". De todo modo, o esforço de separação de d. Cabral é epitomizado em sua proposta de transformar a Igrejinha em um museu de arte moderna, argumentando no sentido de uma adequação entre suas características estéticas e seus fins.

Em reação, artistas, críticos de arte, arquitetos e simpatizantes da Igrejinha contra-atacam reforçando suas qualidades estéticas e sua adequação para finalidade religiosa. É notável a ausência de intervenções desses atores a respeito da primeira linha argumentativa do arcebispo belorizontino, acerca do imperativo canônico da participação e do aval da autoridade religiosa para construção de templos. Ao ignorar tal princípio, desconsidera-se a autonomia religiosa para regular seus espaços e interesses. Ao mesmo tempo, é através da legitimação artística e arquitetônica da Igrejinha da Pampulha que seus defensores procu- 
ram validar sua aplicação religiosa. Trata-se nesse sentido de demandar uma abertura da religião para a "intervenção" da arte/arquitetura de vanguarda. Como nos lembra Asad (1993), tal expectativa se afina com o lugar diferenciado ocupado pelas diferentes modalidades artísticas no projeto moderno: o de lócus sagrado de produção, aperfeiçoamento e libertação do indivíduo subjetivado. Contrariamente ao que se passa com os princípios religiosos, os critérios estéticos são acolhidos e valorizados como alicerces de uma "razão pública" moderna. No mesmo sentido, enfocando o modernismo brasileiro, Holston (1993) sublinha a aposta no potencial da arquitetura de não apenas transformar a vida urbana, mas aprimorar a governabilidade, a racionalidade e, enquanto manifestação artística, renovar a vida social.

Desse modo, argumentos que legitimam o valor artístico e arquitetônico da Igrejinha da Pampulha, procurando conectá-la a uma linhagem barrocaconsiderada fundante da identidade nacional - são suficientes para garantir sua adequação à finalidade religiosa para qual foi planejada. Muito embora a patrimonialização opere como uma legitimação desse argumento estritamente "cultural", não se pode afirmar que tenha colaborado para eliminar o risco de sua musealização ou garantir sua destinação (exclusivamente) religiosa. Isto porque se é fato que a Igreja Católica finalmente consagra o templo em 1959, reconhecendo sua "conversão" e autorizando-Ihe a realização de atividades religiosas, seus usos atuais indicam que a finalidade museológica está também muito viva, como atestam os mais de vinte mil turistas que a visitam anualmente ${ }^{28}$.

Paola Lins de Oliveira é antropóloga, autora de Arte e religião em controvérsia (Rio de Janeiro, Mar de Ideias, 2016) e coorganizadora de Olhares sobre o patrimônio religioso -Rio de Janeiro (Rio de Janeiro, Mar de Ideias, 2016). Atualmente é pesquisadora de pós-doutorado no Programa de Pós-Graduação em Ciências Sociais da UER].

\section{REFERÊNCIAS BIBLIOGRÁFICAS}

ASAD, Talal

1993 Cenealogies of Religion. Discipline and Reasons of Power in Christianity and Islam; Baltimore, The Johns Hopkins University Press.

2003 Formations of the Secular: Christianity, Islam, Modernity. Stanford, Stanford University Press.
28 Levantamento da Belotur-agência de turismo da capital mineira - feito em 2008 contabilizou 24.885 visitantes à Igrejinha da Pampulha. 
BAPTISTA, Anna Paola P.

1999 "Modernismo e tradição na arte religiosa: a querela da

Pampulha". Locus-Revista de História, v. 5, n. 2.

2002 Oeterno ao moderno: arte sacra católica no Brasil - anos 40-

50. Rio de Janeiro, tese de doutorado, UFR].

CAUSSÉ, Françoise

2010 La Revue 'L'Art Sacré': Le Débat en France sur l'art et la

religion (1945-1954). Paris, Les Éditions du Cerf.

CHOAY, Françoise

2006 A alegoria do patrimônio. São Paulo, Estação Liberdade/Unesp.

CHUVA, Márcia Regina Romeiro

2009 Os arquitetos da memória: sociogênese das práticas de preservação do patrimônio cultural no Brasil (anos 1930-1940). Rio de Janeiro, Editora UFR].

COSTA, Lucio

(1953) 2003 "Oportunidade perdida". In XAVIER, A. (org.). Depoimento de uma geração-arquitetura moderna brasileira. São Paulo, Cosac \& Naif.

FABRIS, Annateresa

2000 "A Batalha da Pampulha". In FABRIS, A. (org.). Fragmentos urbanos: representações culturais. São Paulo, Studio Nobel.

FAVRET-SAADA, Jeanne

1992 "Rushdie et compagnie. Préalables à une anthropologie du blasphème". Ethnologie Français, 22(3): 251-260.

CAMBONI, Dario

1997 The Destruction of Art: Iconoclasm and Vandalism since the French Revolution. Londres, Reaktion Books.

GIUMBELLI, Emerson

2002a O fim da religião. Dilemas da liberdade religiosa no Brasil e na França. São Paulo, Attar/Pronex.

2002b 'Para além do 'trabalho de campo': reflexões supostamente malinowskianas". Revista Brasileira de Ciências Sociais, vol. 17, n. 48: 91-107.

2008 "A modernidade do Cristo Redentor". DADOS - Revista de Ciências Sociais, Rio de Janeiro, v. 51, n. 1: 75-105. 
2011 "Brasileiro e europeu: a construção da nacionalidade em torno do monumento ao Cristo Redentor do Corcovado".

Cadernos de Antropologia e Imagem, v. 24/1: 35-63.

CONÇALVES, Reginaldo

1996 A retórica da perda: os discursos do patrimônio cultural no

Brasil. Rio de Janeiro, Editora UFRJ/IPHAN.

HOLSTON, James

1993 A cidade modernista: uma crítica de Brasília e sua utopia. São Paulo, Companhia das Letras.

KOPYTOFF, Igor

1986 "The Cultural Biography of Things: Commoditization as Process". In APPADURAI, A. (org.). The Social Life of Things. Commodities in Cultural Perspective. Cambridge, Cambridge University Press.

KUBITSCHEK, Juscelino

1976 Meu caminho para Brasília: a escalada política.

Volume II. Rio de Janeiro, Bloch.

LATOUR, Bruno

2005 Reassembling the Social: An Introduction to Actor-Network Theory. Oxford, Oxford University Press.

2008 "O que é Iconoclash? Ou há um mundo além das guerras de imagens". Horizontes Antropológicos, v.14, n.29: 111-150. Disponível em: http://www. scielo.br/pdf/ha/v14n29/a06v14n29.pdf, acesso em 20 de agosto de 2009.

MENEZES, Ivo Porto de

1962 Arquitetura sagrada. Ouro Preto, tese de concurso para a cadeira de "Construção Civil, Arquitetura, Higiene, Saneamento, Urbanismo", Escola de Minas.

OLIVEIRA, Paola Lins de

2014 Oferendas modernas: religião, arte e política na construção de obras-lugares no Brasil e na França. Rio de Janeiro, tese de doutorado, PPCSA/IFCS/UFR].

ROBERT, Valérie

2003 Intellectuels et polémiques dans l'espace germanophone. Paris, PIA. 


\section{ABSTRACT}

The article focuses on the early years of the cultural biography of the Church of St. Francis of Assisi, located in Pampulha, Belo Horizonte-MG. The "Igrejinha da Pampulha" is part of a plan of urban modernization conceived in the early $1940 \mathrm{~s}$ by the then-mayor of the state capital, Juscelino Kubitschek, giving rise to the Pampulha Architectural Complex. Designed by the architect Oscar Niemeyer, and decorated mainly by the artist Candido Portinari, the building is not accepted by the local religious authorities, establishing a public controversy between supporters and critics of their consecration. The interest that anchors this analysis lies in the way the building grounds, condenses and stimulates consortia between religious, artistic and political dimensions, while its creators, critics and defenders oscillate between, on the one hand, support of such associations and, on the other, the defense of the distinctions between the same dimensions, both to support as to criticize them. This is therefore a case where what is at stake is the constant tension of the modern paradigm of separation and autonomy of religious, artistic and political bodies.

Recebido em 5 de junho de 2104. Aceito em 14 de dezembro de 2017.

\section{KEYWORDS}

Igrejinha da

Pampulha, Public

Controversy, Modern

Art, Religious

Art, Religious

Architecture 